\title{
A Demand-Side Analysis of Renminbi Internationalisation: The Renminbi in South Korea
}

\author{
Hyoung-kyu Chey
}

April 2014

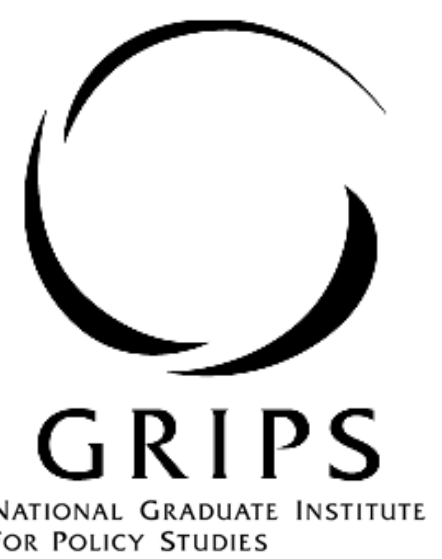

National Graduate Institute for Policy Studies 7-22-1 Roppongi, Minato-ku,

Tokyo, Japan 106-8677 


\title{
A Demand-Side Analysis of Renminbi Internationalisation: The Renminbi in South Korea
}

\author{
Hyoung-kyu Chey ${ }^{*}$
}

\begin{abstract}
As the internationalisation of the renminbi has progressed rapidly in recent years, research on it has also grown considerably. However, most of this research tends to focus mainly on analysing it from the supply side, looking, for example, at China's economic and political conditions and related policy measures. Meanwhile, the demand side of renminbi internationalisation remains underexplored. This study addresses this critical gap in the literature by providing an in-depth analysis of use of the renminbi in South Korea. It demonstrates that renminbi use in the country is still very limited in both the private and the public sectors. It also finds that neither sector has much intention of increasing its use of the renminbi in the near future, as its costs overwhelm its benefits. These findings suggest that, contrary to many optimists' anticipation, evolution of the renminbi into a consequential international currency even in East Asia may not be an inevitable outcome for China, despite the country's spectacular economic rise.
\end{abstract}

Keywords: currency internationalisation, international currency, renminbi, yuan

JEL classifications: F33

\section{INTRODUCTION}

Since the outbreak of the 2008-09 global financial crisis the Chinese authorities have adopted a variety of policy measures to actively promote internationalisation of their own currency, ${ }^{1}$ the renminbi, in order to reduce China's reliance on the US dollar, accelerate domestic financial reforms, strengthen its national pride and international status, etc. ${ }^{2}$ As a result, although its absolute level is still quite low global use of the renminbi has grown remarkably within only a few years. For example, the share of China's trade settled in the

\footnotetext{
* Associate Professor of International Political Economy, National Graduate Institute for Policy Studies, 7-221 Roppongi, Minato-ku, Tokyo 106-8677, Japan, email: hyoung-kyu@grips.ac.jp.

${ }^{1}$ The policy measures to facilitate renminbi internationalisation have focused mainly on increasing the use of the renminbi in trade settlement and on developing offshore renminbi markets, particularly in Hong Kong, while opening up of the mainland financial market has been proceeding only gradually. For details on such policy measures, see Craig et al. (2013) and Eichengreen (2013).

${ }^{2}$ The Chinese authorities have not officially announced the goals of renminbi internationalisation. A good number of studies have however attempted to identify them. See, for example, Kwon (2013), Kroeber (2013), Mallaby and Wethington (2012), Pettis (2012), Thornton (2012) and Yu (2014).
} 
renminbi rose to 16.6 per cent in the first quarter of 2013, up from a mere 0.4 per cent three years earlier. ${ }^{3}$ In addition, letters of credit (L/Cs) labelled in renminbi accounted for 8 per cent of the global L/C market in 2012, making the renminbi the third most largely used currency in the market (Euromoney, 2013). The size of renminbi bank deposits in Hong Kong rose from 40 billion renminbi in January 2008 to 827 billion renminbi in November 2013, and the stock of so-called 'dim sum' bonds in Hong Kong grew from 12 billion to 382 billion renminbi between 2008 and December 2013. A wide range of offshore renminbi financial products have been introduced, including renminbi Exchange Traded Funds and derivatives (Craig et al., 2013, pp. 4-5). The renminbi-denominated direct investments into and from China reached 448 billion and 86 billion renminbi respectively in 2013. Foreign central banks, including those of Malaysia, Nigeria, Chile, South Korea and Thailand, have begun to hold renminbi-denominated assets as parts of their foreign exchange reserves (Jones, 2013; Thornton, 2012, p. 13). ${ }^{4}$

Along with this impressive progress in renminbi internationalisation, research on the subject also has exploded in recent years, most of it ultimately focusing on its future prospects. During the first few years of renminbi internationalisation, a majority of studies tended to express reasonably sceptical or cautious views on the future of the renminbi. ${ }^{5}$ As it has taken off fairly successfully, however, the number of more sanguine forecasts has been growing. ${ }^{6}$ Some studies even claim that a renminbi bloc has already been formed in East Asia, implying the emergence of a multiple currency system in the world. ${ }^{7}$

Despite such substantial growth in the literature, however, there remain many important issues that have not yet been systematically addressed. One such issue is the actual use of the renminbi in ordinary foreign countries - those not having either unique political relations with China, such as Hong Kong, or international financial centres such as London. Most studies of renminbi internationalisation tend to provide supply-side analyses, focusing on China's economic, and also sometimes political, conditions for renminbi internationalisation - such as its economic size and participation in global trade, its financial market development, its capital account openness, its price level, its domestic

\footnotetext{
${ }^{3}$ Although the volume of Chinese imports settled in the renminbi initially overwhelmed that of Chinese exports, due to factors such as the Chinese tax rebate scheme, they have come roughly into balance in recent years. For more on this issue, see Craig et al. (2013, pp. 14-15).

${ }^{4}$ There are currently two indexes of renminbi internationalisation. One is the Renminbi Internationalisation Index announced by the International Monetary Institute of Renmin University of China, which takes into account the shares of renminbi use in trade, financial transactions and foreign exchange reserves (Kim, 2013, p. 5). The other is the Renminbi Globalisation Index of Standard Chartered, a global bank. This index measures international use of the renminbi in four areas - deposits, dim sum bonds and certificates of deposits, trade settlement and other international payments, and foreign exchange - covering the top three offshore renminbi markets of Hong Kong, London and Singapore (Standard Chartered, 2013). Both indexes have revealed significant progress in renminbi internationalisation in recent years.

${ }^{5}$ See, for example, Chen and Cheung (2011), Chey (2013), Cohen (2012; 2014), Dobson and Masson (2009), Eichengreen (2013), Helleiner and Malkin (2012), Lee (forthcoming), Mallaby and Wethington (2012), Park (2010), $\mathrm{Wu}(2009)$ and $\mathrm{Wu}$ et al. (2010).

${ }^{6}$ See, for example, Liao and McDowell (2013), Subacchi (2013) and Subramanian (2011a; 2011b).

${ }^{7}$ See, for example, Campanella (2014), Fratzscher and Mehl (2011), Ito (2010) and Subramanian and Kessler (2012).
} 
political support for renminbi internationalisation, its political institutions, its policy measures for renminbi internationalisation, its international power, and so on. They also tend to rely mainly on the data on mainland China and the offshore renminbi centres, especially Hong Kong, in examining the level of global renminbi use. Such a supply-side analysis of renminbi internationalisation is undoubtedly necessary and important. It has a critical limitation, however, in that it pays little attention to actual use of the renminbi in ordinary foreign countries. In fact, the supply-side analysis usually addresses the costs and benefits of using the renminbi from the Chinese perspective only, rather than from foreign users' perspectives. This is a serious shortcoming, as renminbi internationalisation ultimately requires use of the renminbi by non-residents. Moreover, even if renminbi internationalisation grows in aggregate at the global level, the levels of renminbi use may vary across countries. It is therefore necessary to explore the uses of the renminbi in individual foreign countries in order to better understand which factors promote or hinder renminbi internationalisation and, going further, currency internationalisation in general.

In this context, this study provides a demand-side analysis of renminbi internationalisation, focusing on the use of renminbi in one ordinary country, South Korea (hereafter Korea). It demonstrates that, although use of the renminbi in that country has recently increased, it remains at a negligible level despite the country's close economic ties with China. It moreover finds that this lack of development in renminbi use in Korea is due to weak demand for the renminbi from both the private and the public sectors. Korean trading firms and financial institutions have little interest in either using the renminbi at present or increasing their use of it in the near future, while the Korean authorities have little intention of providing policy support to encourage renminbi use in their country. The shortage of renminbi investment options and the high transaction costs of renminbi use hinder firms from using the currency, while financial institutions' low competitiveness in the renminbi business also leads them to drag their feet. Meanwhile, the authorities' indifference to the renminbi may be explained by the minimal immediate domestic economic and political importance of the renminbi, as well as by the country's political economic position between China and the United States. These findings suggest that evolution of the renminbi into an influential international currency may not be inevitable, even in East Asia, at least in the near future, despite China's spectacular economic growth over the past decades.

In analysing renminbi use in Korea, this study employs a qualitative analysis, including through in-depth interviews with bankers, policymakers and experts in various relevant institutes such as the Ministry of Finance and Strategy (MoFS), the Bank of Korea (BoK), the Korea Trade-Investment Promotion Agency (KOTRA), the Korea International Trade Association (KITA), the Korea Center for International Finance (KCII), the Korea Institute for International Economic Policy (KIEP) and the Korea Capital Market Institute (KCMI), as well as major private banks both domestic and foreign-owned. Korea has been chosen as a research case since it offers various analytic advantages in this regard, which will be discussed in greater detail in the following section.

The remainder of this paper is organized as follows. The next section highlights the need for a demand-side study of renminbi internationalisation. The subsequent section will examine the use of the renminbi in Korea. The following two sections will then provide 
accounts of the low use of the renminbi in the country, first addressing the private sector and then the public sector. The final section concludes, discussing the major implications of this study.

\section{NEED FOR A DEMAND-SIDE STUDY}

The literature on renminbi internationalisation deals primarily with its feasibility, offering varying conclusions in this regard. ${ }^{8}$ Some studies adopt quantitative methods, one good example being Lee (forthcoming). Following Chinn and Frankel's (2008) analysis of the internationalisation of the euro, Lee adopts an economy's global shares of gross domestic product and trade, along with its degree of financial market development, price level and network externalities, as the major determinants of its currency's internationalisation. He also presents the forecast that, conditional on further development in terms of its convertibility, the renminbi can gradually become an international currency that accounts for around 3 to 12 per cent of the world's international reserves by 2035 . Meanwhile, another group of studies examine the co-movements between the renminbi and other currencies, based mostly on the Frankel and Wei (1994) methodology. Although there are a few exceptions that foresee continuing dominance by the US dollar as the primary anchor currency in East Asia, such as Kawai and Pontines (2014), most of these studiesincluding Fratzscher and Mehl (2011), Ito (2010) and Subramanian and Kessler (2012) make bolder claims that a renminbi bloc has already been established in East Asia, suggesting that the international monetary system has now been transformed into a multipolar currency one.

There are a good number of studies adopting more qualitative methods as well. A majority of them - including Chen and Cheung (2011), Cohen (2012; 2014), Dobson and Masson (2009), Park (2010), Subacchi (2013), Subramanian (2011a; 2011b), Wu (2009), Wu et al. (2010) and Yu (2014) — mainly address China's economic conditions such as its economic size, share in global trade, financial market development, capital account liberalisation, price stability, etc., which they regard as the key factors affecting renminbi internationalisation, similar to the views in Chinn and Frankel (2008) and Lee (forthcoming) mentioned above. In contrast, some studies pay more attention to the political conditions surrounding renminbi internationalisation. Chey (2013), for example, examines China's international power as a crucial determinant of renminbi internationalisation. Helleiner and Malkin (2012) explore the domestic political support in China for renminbi internationalisation. Eichengreen (2013) and Eichengreen and Kawai (2014) stress the impacts on renminbi internationalisation of China's domestic political institutions, such as its authoritarian political regime and the weak independence of the People's Bank of China (PBoC), its central bank. In general, these qualitative studies tend to be more cautious about the feasibility of rapid renminbi internationalisation, although there are some positive views such as those of Campanella (2014), Subacchi (2013) and Subramanian (2011a; 2011b).

\footnotetext{
${ }^{8}$ Meanwhile, there are a few studies that address China's motivations for renminbi internationalisation. See, for example, Kroeber (2013) and Kwon (2013).
} 
Most of the existing studies, however, irrespective of their differences in methodologies or arguments, share two common characteristics. First, they tend to focus on the issue from the Chinese side, analysing China's own economic or political conditions and its government strategies and policies, although many do also recognise the importance of foreign demand for the renminbi if its internationalisation is to succeed. In other words, they tend to provide supply-side analyses of renminbi internationalisation. This approach to the issue is obviously necessary and desirable in several respects. It has a notable limitation, however, in that it pays little attention to the demand side of renminbi internationalisation, that is, how foreign countries actually perceive and respond to renminbi internationalisation and the Chinese government policies promoting it. Yet internationalisation of the renminbi fundamentally means the use of the currency by non-residents, and it is thus necessary to analyse how willing foreigners are to use the renminbi and how much they actually are doing so. And this requires examination of the costs and benefits of renminbi use from foreigners' perspectives, while the supply-side analysis tends in contrast to consider the Chinese perspective only. ${ }^{9}$ Moreover, different foreign countries may have different preferences, some higher but some lower, regarding renminbi use. An analysis concentrating on the Chinese side only cannot address such differences in preferences and responses to the renminbi, even despite their having potentially significant implications for study of the factors affecting renminbi internationalisation and, going further, currency internationalisation in general.

The other common element shared in the literature is that it tends to assess the degree of renminbi internationalisation by relying mainly on the data on mainland China and the offshore renminbi centres, particularly Hong Kong. Meanwhile, the degree of use of the renminbi in ordinary foreign countries has rarely been explored, resulting in a failure therefore to analyse the actual demand for renminbi use in those countries. Such an analysis may however provide an inflated or distorted assessment of renminbi internationalisation, given that Hong Kong accounts for the majority of total global renminbi use. For example, although Hong Kong's share in global use of the renminbi has recently declined to some extent, some 74 per cent of the world's renminbi payments in December 2013 were made there (SWIFT, 2014). Likewise, more than 80 per cent of China's renminbi trade settlement is with Hong Kong (Eichengreen and Kawai, 2014, p. 5), with a majority of those using the renminbi in Hong Kong actually from the mainland. ${ }^{10}$ The appropriateness of treating Hong Kong as a 'foreign' region in analysing 'internationalisation' of the renminbi is also not clear, as despite its administrative independence the city is essentially a part of China. There are a few studies that pay attention to the use of the renminbi in ordinary foreign countries. The above-mentioned analyses of co-movements between the renminbi and foreign currencies are examples. These studies also have significant drawbacks, however, in concentrating merely on one monetary function of an international currency-that is, its

\footnotetext{
${ }^{9}$ For a discussion of the costs and benefits of renminbi internationalisation for China, see Chey (2013, pp. 350-51).

${ }^{10}$ For example, Chinese state-owned banks or big Chinese commercial banks accounted for more than 55 per cent of all dim sum bonds issued in 2012 and 2013 (Song, 2013b). See also Eichengreen and Kawai (2014, p. 7).
} 
use as a reference currency for exchange rate pegging — neglecting its other important monetary functions such as its uses as a trade invoicing and settlement currency, investment asset or foreign reserve currency. ${ }^{11}$

In an attempt to fill in the gaps left by such critical shortcomings of the supply-side approach, this study provides a demand-side analysis of renminbi internationalisation. ${ }^{12}$ It focuses on the use of the renminbi in an ordinary foreign country, Korea. And it addresses both the current level of renminbi use in that country and the inclination in that country to use the renminbi, which carries significant implications for the future. In this process this study explores the costs and benefits of using the renminbi for Korean users themselves, rather than Chinese ones, in contrast to the concerns of the supply-side analysis. This demand-side research ultimately tackles the salient question of whether the supply-side efforts from China to promote renminbi internationalisation have affected the preferences of foreigners regarding renminbi use.

The selection of Korea as the study case offers considerable analytical advantages for the study of renminbi internationalisation. First, the geographical area in which renminbi internationalisation is most likely to develop in its initial stage is Asia (it is in fact widely suspected that the Chinese authorities aim to develop the renminbi into a regional currency in Asia first), and Korea is one of the major countries in that region. In addition, Korea has a very close economic relationship with China, with China for example being its largest trading partner in terms of both exports and imports. ${ }^{13}$ Moreover, Korea has recorded a large trade surplus vis-à-vis China over the past decades, especially since 2008, implying a strong potential for it to use the renminbi. Korea also became the largest exporter to China in 2013, while China is the largest foreign investor in the Korean bond market. The size of the bilateral local currency swap arrangement between the BoK and the $\mathrm{PBoC}$ is also the second largest among the PBoC's total of 23 currency swap arrangements (as of January 2014), after only Hong Kong. In these circumstances, the use of the renminbi in Korea may have significant implications for the future of its internationalisation. If Korea has strong motivations to use it, this may suggest a positive future for the renminbi's internationalisation in East Asia. If Korea is reluctant to do so, however, even despite its close economic ties with China, the implication may be the opposite.

This study's focus on the case of one country also enables it to conduct an in-depth analysis of that case. Indeed, this research addresses the use of the renminbi in various monetary areas, including for trade settlement, private investment assets and foreign exchange reserves, while distinguishing between renminbi use in the private and in the public sectors. As a result, it can provide a balanced and systematic assessment of the use of the renminbi in Korea.

\footnotetext{
${ }^{11}$ For the various monetary functions of international currencies, see Chey $(2012 ; 2014)$.

${ }^{12}$ Liao and McDowell (2013) also provide a demand-side analysis of renminbi internationalisation. Their analytic focus is narrow, however, in only addressing the bilateral local currency swap arrangements between China and foreign countries.

${ }^{13}$ From January to November 2013, the shares of exports to and imports from China accounted for about 26 and 16 per cent of total Korean exports and imports, respectively.
} 


\section{RENMINBI USE IN KOREA}

Just as at the global level, the recent growth in renminbi use in Korea seems quite remarkable at first glance as well. The volume of Korean exports settled in the currency rose from 3 million dollars in 2008 to 1.3 billion dollars in 2012, while that of Korean imports soared from 48.5 million to 256.2 million dollars during the same period. The total amount of renminbi deposits in the country increased from 10 million dollars at end-2009 to 1.6 billion dollars in October 2013. A Korean firm issued a dim sum bond for the first time in July 2011, and this was followed by issuance by eleven other Korean firms in the following year (BoK, 2013b; Kim, 2013, p. 14). Fifteen Korean financial institutions, including the BoK, Korea Investment Corporation (KIC) and the National Pension Service, as well as private ones, are participating in the Qualified Foreign Institutional Investor (QFII) scheme, which allows licensed foreign investors to invest in mainland securities and fixed incomes by switching dollars into renminbi. ${ }^{14}$ The BoK is also participating in the Chinese mainland interbank bond market. In addition, the BoK and the PBoC established in December 2008 a bilateral local currency swap arrangement, which as mentioned earlier is the second largest among the PBoC's currency swap arrangements (at 360 billion renminbi/64 trillion won). ${ }^{15}$ In December 2012 they then also introduced a system for using this currency swap arrangement for the provision of local currency liquidity for trade settlement, which can function as a stable liquidity pipeline of renminbi for Korean firms (BoK and MoFS, 2012). ${ }^{16}$ The BoK made the first renminbi loan to a domestic bank through this swap arrangement, worth 62 million renminbi, in January 2013 (MoFS, 2013).

Despite this notable increase in renminbi use in Korea, however, it is misleading to argue that the renminbi is beginning to be widely used there. On the contrary, its use in Korea is still vastly limited. The share of Korean exports settled in the renminbi amounted to a mere 0.4 per cent during the third quarter of 2013. Moreover, it was only 1.5 per cent even for exports to China during that period. ${ }^{17}$ The import side is even less propitious. The share of Korean imports settled in the currency reached a mere 0.1 per cent in the same period, with the share for imports from China itself also marking a historical high of just 0.8 per cent. In fact, use of the Korean won for settlement of Chinese imports during the period was higher, reaching 1.3 per cent. ${ }^{18}$

\footnotetext{
${ }^{14}$ The total number of QFII participants was 229 as of July 2013. Meanwhile, the Renminbi Qualified Foreign Institutional Investor scheme, which allows investors to invest in mainland equities and bonds by using offshore renminbi, was launched in December 2011. Initially only Hong Kong subsidiaries of Chinese fund managers were eligible to participate in this scheme, but it was then opened to Hong Kong financial institutions in March 2012, and to London and Singapore in July 2013.

${ }^{15}$ The BoK established the swap arrangement during the global financial crisis as a means for crisis prevention. Its initial duration was three years, but it has been renewed twice so that the current expiration date is October 2017. Its size was also doubled in 2011, from the initial 180 billion renminbi/38 trillion won to 360 billion renminbi/64 trillion won (BoK, 2013c).

${ }^{16}$ The size of the swap arrangement is equal to 30 per cent of the total volume of trade between the two countries.

${ }^{17}$ The share reached 1.8 per cent, its historical peak, in the second quarter of 2013.

${ }^{18}$ The data on trade settlement currency composition is available from the Bank of Korea.
} 
At this point, it should be emphasised that Korea's use of the renminbi in trade settlement concentrates almost exclusively on China. During 2012, for example, while the total volume of renminbi-settled exports amounted to 1,338 million dollars, the amount of renminbi-settled exports to China made up 1,333 million dollars of this. Likewise, the total size of renminbi-settled imports that year was 256 million dollars, among which the volume of imports from China was 255 million dollars. These figures demonstrate that Korea barely uses the renminbi at all for trade settlement with non-Chinese counterparts.

In addition, Korean firms have hardly utilized renminbi lending through the PBoC-BoK currency swaps. The volume of renminbi loans extended through this channel has not grown substantially since the first loans were made in January 2013, despite the advantage of their interest rates being stable, based on the Shanghai Interbank Offered Rate (SHIBOR). (While the SHIBOR is in fact a bit higher than interest rates paid for raising renminbi funds in the Hong Kong offshore renminbi market, ${ }^{19}$ those rates are volatile so that borrowers tend to hedge. In terms of the actual costs that borrowers have to bear, therefore, renminbi funds provided through the currency swaps are not necessarily less competitive than those raised in Hong Kong. ${ }^{20}$ ) And this low utilization of these currency swap funds thus suggests the minimal interest of Korean firms in use of the renminbi for trade settlement.

Meanwhile, Korean firms' participation in the dim sum bond market has also declined. There were only two firms that issued dim sum bonds in the period from January to July 2013 (Kim, 2013, p. 14). In addition, the QFII quotas of some Korean financial institutions - such as Korea Development Bank and Tong-Yang Asset Management - have been reduced since they have not invested their full quota amounts. Such reductions in QFII quotas are quite exceptional, in a situation where the Chinese authorities have been increasing the total QFII volume (Chung, 2013). Also, despite a rise in the size of renminbi deposits in Korea its share is as yet marginal, accounting for just 3.5 per cent of total foreign currency deposits in the country in October 2013, in contrast to the dollar's share of 84.6 per cent (BoK, 2013a).

As to the use of the renminbi in Korea's foreign exchange reserves, although the BoK has begun to hold renminbi-denominated assets by participating in the QFII and in the mainland interbank bond market, their size is extremely trivial. In greater detail, the BoK's QFII quota was initially 300 million dollars only. ${ }^{21}$ And although its quota was doubled to 600 million dollars in January 2014, this accounts for just 0.17 per cent of the BoK's total foreign exchange reserve holdings. The BoK's investment in the mainland interbank bond market meanwhile amounts to 3.2 billion dollars, which is just 0.92 per cent of its total foreign exchange reserves. Thus, all renminbi-denominated assets held by the BoK account for around only 1 per cent of its total foreign exchange reserves.

\footnotetext{
${ }^{19}$ In late June 2013, for instance, rates in Hong Kong were 0.6\% while the SHIBOR was 2.14\% (BoK, 2013d).

${ }^{20}$ Author interview with Kim Woong Ryeol, Deputy General Manager, Woori Bank Samsungdong Branch (former Deputy General Manager, Foreign Exchange Business Department), 12 September 2013, Seoul.

${ }^{21}$ The BoK invested all 300 million dollars in 'A' shares on the Shanghai and Shenzen bourses. Meanwhile, the QFII quota of KIC is also limited to 400 million dollars (Chung, 2013).
} 
Given all of this, it appears fair to assess the use of the renminbi in Korea as still quite marginal. It is true that there has been a remarkable increase in renminbi use there, compared with the past. But this rise is illusory, as it began from a very low base of almost zero. And therefore, given that renminbi internationalisation is still in its early stage, a more essential issue for its future will be whether foreigners, as exemplified here by Koreans, are inclined to increase their use of the currency going forward. The following two sections will address this salient question.

\section{WEAK MARKET INCENTIVES}

The minimal use of the renminbi in Korea stems most of all from the low private sector interest in using the currency. Both firms and financial institutions are highly reluctant to use the renminbi, as it generates substantial costs without yielding meaningful benefits. For most Chinese firms international use of the renminbi is certainly beneficial in many aspects, including the elimination of exchange risk and exchange commissions and greater ease in business management and accounting. But Korean users in contrast bear great costs in using the renminbi, at least at this early stage of renminbi internationalisation.

To address Korean firms first, among the most crucial obstacles hindering them from using the renminbi are the limited investment options for the currency. In other words, due to the underdevelopment of renminbi financial products in Korea there is little that they can do with any renminbi acquired. Renminbi deposits are the only meaningful investment product in the Korean financial markets. Even worse, among a total of seven major commercial banks, two banks (Shinhan Bank and Citi Bank Korea) do not offer renminbi accounts for either demand or time deposits, while two others (Kookmin Bank and Korea Exchange Bank) offer demand deposit accounts with zero interest rates only. There are just three banks (Woori Bank, Standard Chartered Korea and Hana Bank) that offer time deposit accounts with positive interest rates - of 3.0 per cent, 1.9 per cent and 0.6 per cent respectively as of January 2014. Yet, since Korean banks typically charge high exchange commissions of around 2 to 3 per cent for renminbi deposits, renminbi depositors actually suffer losses at most banks. In addition, some Korea banks have ceilings on renminbi deposits. Korea Exchange Bank, for example, limits the total volume of its renminbi deposits to 5 million dollars, and that of an individual renminbi deposit account to 50,000 dollars only. ${ }^{22}$ This underdevelopment of renminbi financial products in the country is due largely to the low interest of Korean financial institutions in the renminbi business, which will be discussed in detail below. However, it also reflects Korean firms' weak inclination for use of the renminbi.

The offshore investment opportunities in Hong Kong are not high, either. The amount of renminbi deposits in Hong Kong is in fact much greater than the volume of dim sum bonds, implying a shortage of renminbi assets for investment. In November 2013, for example, the former reached 827 billion renminbi while the latter amounted to just 380 billion renminbi. In fact, large mainland corporations hardly issue dim sum bonds as they have few difficulties in raising funds at attractive rates on the mainland, mainly through bank loans,

\footnotetext{
${ }^{22}$ Author interview with an anonymous banker at Korea Exchange Bank, 17 September 2013, by telephone.
} 
which reduces the investment opportunities for offshore renminbi holders (Kroeber, 2013, p. 16). The lower costs of raising renminbi funds in Hong Kong than on the mainland reflects to some extent this limitation of available offshore renminbi investment products. Meanwhile, the limited capital account openness on the mainland constrains foreign investment in its financial markets, although the Chinese authorities do plan to significantly increase capital account liberalisation in the near future. This finding, that the limited investment opportunities for holders of renminbi deter Korean firms from using the currency, supports the widely-accepted emphasis in the literature on the need for Chinese capital account liberalisation to facilitate renminbi internationalisation.

Another major obstacle to renminbi use is its high transaction costs, which are also due to the underdevelopment of the renminbi markets. If Korean exporters use renminbi L/Cs they have to pay much higher exchange rate commissions than when using dollar L/Cs (Choi, 2011). ${ }^{23}$ Meanwhile, Korean exporters' use of renminbi remittances for trade payments provides few benefits compared to their use of the dollar, unless their Chinese counterparts happen to be their own subsidiaries or they need to use the renminbi to satisfy their Chinese buyers. ${ }^{24}$ Likewise, Korean importers' uses of the renminbi through either L/Cs or remittances also do not normally generate meaningful benefits to them (Choi, 2011). Yet when Korean firms use the renminbi for trade settlement they face the related exchange risks. And although firms can hedge against the renminbi in the Hong Kong offshore renminbi market, the hedging products and the financial institutions offering such services are limited, with the result of higher hedging costs for the renminbi than for the dollar. It should moreover be noted that, even when Korean firms use the renminbi for trade settlement with some Chinese trade partners, many of them still have to continue to use the dollar for other trading partners. And this means that many Korean firms have to handle double exchange risks - both for the dollar and for the renminbi-if they use the renminbi, which increases their costs. In addition, there is no renminbi clearing bank in Korea yet, so that renminbi settlements for Korean users have to be conducted through Hong Kong, where the Bank of China Hong Kong offers renminbi settlement services.

In fact, many Chinese exporters are even willing to offer discounts, of around 3 to 5 per cent, to foreign importers agreeing to use the renminbi for settlement, as the Chinese exporters can then reduce their exchange rate risks and various operational costs while they also expect the renminbi to appreciate (Euromoney, 2013; Lee, 2012a). The use of the renminbi by Korean firms is nonetheless still trivial, suggesting that such discounts do not provide incentives strong enough to induce them to increase their renminbi use and implying in turn that their costs generated from renminbi use are substantial. And indeed, when the KOTRA held a briefing explaining renminbi trade settlement in December 2012, there were very few Korea firms expressing any interest in it. ${ }^{25}$ Ultimately, there is at

\footnotetext{
${ }^{23}$ Woori Bank, for instance, one major Korean commercial bank, charged as an exchange commission 7.1 per cent for renminbi L/Cs as of August 2013, compared to only 2.3 per cent for dollar L/Cs.

${ }^{24}$ If Chinese importers are Korean exporters' subsidiaries, the benefits from renminbi use accruing to their Chinese subsidiaries may be shared with the parent Korean firms (Choi, 2011).

${ }^{25}$ Author interview with Park Han Jin, Director, China Business Department, KOTRA, 17 September 2013, Seoul.
} 
present almost no voluntary desire on the parts of Korean firms to use the renminbi for trade settlement. $^{26}$

Korean financial institutions also appear to have minimal interest in business involving the renminbi. With regard to renminbi businesses, most Korean banks tend to focus on trade-related businesses only, rather than on developing financial transactions. Even in trade-related businesses, they-including Woori Bank, the domestic bank most involved in the renminbi business - are largely passive, merely responding to demand from clients rather than actively cultivating it. ${ }^{27}$ Indeed, when the KOTRA held its December 2012 briefing on renminbi trade settlement mentioned earlier, it had difficulties finding Korean banks to participate as they were uninterested. ${ }^{28}$ Korean banks, moreover, appear to conduct trade-related renminbi businesses as part of their marketing activities, rather than in accordance with their renminbi business strategies per se. $^{29}$

Korean banks' neglect of the renminbi business appears to stem largely from their low competitiveness in the renminbi markets vis-à-vis Chinese and global banks. Although Korean banks have advanced into China, they have not been able to strengthen their competitiveness in the renminbi business due to the limited liberalisation of the Chinese financial markets. ${ }^{30}$ In the meantime, Korean banks are also lacking in professional manpower in the renminbi business. ${ }^{31}$ Chinese banks' Korean branches are in fact usually more active than Korean banks in the renminbi business in Korea. They wish to dominate the renminbi markets in the country in advance, ${ }^{32}$ and, as one of their means to this end, generally pay higher interest rates for renminbi deposits of about 2 per cent, through certain unofficial ways. ${ }^{33}$

Standard Chartered Bank Korea, a foreign owned bank, may be one exception that is in fact active in the renminbi business in Korea. It offers relatively high interest rates, as mentioned above, while at the same time temporarily exempting customers from exchange commissions, which would normally be 2.5 per cent. It does not have any ceiling for renminbi deposits, either. As a result, the amount of its renminbi deposits is the largest in Korea. Standard Chartered Bank Korea is also the one bank that delivered a presentation during the aforementioned briefing on renminbi trade settlement hosted by the KOTRA in 2012. However, even this bank's great interest in the renminbi business is not based on expectations of high profits from the renminbi business per se, although its parent bank is one of the leading global banks in that business. Rather, Standard Chartered Bank Korea also uses the renminbi business as a means of expanding its corporate clients, after the

\footnotetext{
${ }^{26}$ Author interviews with Kim Woong Ryeol; Park Han Jin; and Lee Bong-Geol, Chief Researcher, Strategic Market Research Team, the Institute for International Trade, KITA, 16 September 2013, Seoul.

${ }^{27}$ Author interview with Kim Woong Ryeol.

${ }^{28}$ Author interview with Park Han Jin.

${ }^{29}$ Author interview with Lee Chi Hun, Deputy Director, Research and Analysis Office, KCIF, Seoul, 6 September 2013.

30 Author interview with Park Han Jin.

${ }^{31}$ Author interview with An Yu Hua, Research Fellow, International Finance Division, KCMI, 11 September 2013, Seoul.

${ }^{32}$ Author interview with An Yu Hua.

${ }^{33}$ Author interview with Lee Chi Hun.
} 
substantial shrinkage in its corporate business when it was previously owned by Newbridge Capital. $^{34}$

At this point, one may ask the following question: what then explains the recent increase in renminbi use in Korea, even if its absolute level is in fact still marginal? One of the most important factors behind the rise in Korean renminbi use appears to be requests from Chinese firms, particularly importers, for use of the renminbi in trade settlement. ${ }^{35}$ It should be stressed, however, that most Chinese requests for renminbi settlement are not forceful or strong, as Chinese firms themselves are well aware of the underdevelopment of the basic infrastructures for renminbi use. ${ }^{36}$ In fact, while a quite good number of Korean firms have received such requests from their Chinese trading partners, particularly importers (Hwang, 2011; Moon, 2011), ${ }^{37}$ only a very limited number of them actually use the renminbi for trade settlement. In many cases, moreover, even the Chinese firms themselves prefer dollar settlement, in part because they import intermediary goods from Korea and export the final products to markets such as the United States. ${ }^{38}$ Secondly, when Korean parent firms trade with their Chinese subsidiaries, they may settle their trade in the renminbi to benefit these Chinese subsidiaries, which may in turn benefit the parent companies as well. ${ }^{39}$ Finally, the expectations of renminbi appreciation may be another incentive for renminbi use. This cannot be a reliable or sustainable market force for renminbi internationalisation, however, as foreigners' desire to hold the renminbi will evaporate quickly if signs of renminbi depreciation emerge.

\section{LITTLE POLICY SUPPORT}

If the Korean authorities provided policy support to encourage renminbi use in their country, the situation might be different. In fact, governments in some countries such as the United Kingdom, Singapore and Taiwan have adopted diverse policy measures - including designation of renminbi clearing banks, allowance of the issuance of renminbi-denominated bonds, and relaxation of financial regulations - in order to develop offshore renminbi centres in their own jurisdictions. ${ }^{40}$ In contrast to their cases, however, the Korean authorities remain indifferent or neutral to internationalisation of the renminbi, and have not taken any meaningful initiatives aimed at helping Korean firms or financial institutions to use the currency.

As to the Korean government, although there is a vague consensus within it in the wake of the global financial crisis on the desirability of reducing the country's dependence on the dollar, it does not consider the encouragement of renminbi use as a means of achieving this.

\footnotetext{
${ }^{34}$ Author interview with Kim Dan Joo, Senior General Manager, Transaction Banking, Standard Chartered Bank Korea, 25 September 2013, Seoul.

${ }_{35}$ Author interviews with Kim Woong Ryeol and Lee Bong-Geol.

${ }^{36}$ Author interview with Lee Bong-Geol.

${ }^{37}$ Indeed, as discussed earlier, renminbi settlement for Korean exports is higher than that for Korean imports.

${ }^{38}$ Author interview with Choi PilSoo, Head, China Research Team, KIEP, 17 September 2013, Seoul.

${ }^{39}$ Author interview with Choi PilSoo.

${ }^{40}$ Regarding such policy measures, see Horny and Jenkins (2013), Part et al. (2013), Song (2013a) and Muk (2013b).
} 
The MoFS has no policy at all, either short-term or medium- to long-term, concerning use of the renminbi. ${ }^{41}$ As one ministry official commented: 'There is no reason why we should use the renminbi... The ministry has never conducted systematic research on the potential impact of renminbi use on the Korean economy.... The renminbi is not an important issue at all (emphases by the author)' ${ }^{42}$ The ministry's stance is fundamentally to follow the markets, meaning that if there is market demand for increased use of the renminbi it will provide the necessary support, but that it has no intention of playing a leading role in encouraging use of the renminbi through policy initiatives. ${ }^{43}$

The renminbi has in addition never attracted meaningful attention among Korean legislators. Exceptionally, one ruling party legislator did propose the idea of developing an offshore renminbi centre in Seoul during the Assembly inspection of the MoFS in September 2011. The vice-minister however responded sceptically to him (NARK, 2011). And while this legislator is almost the only one who has ever expressed serious interest regarding the renminbi, he was not re-elected in 2013. Meanwhile, one incumbent ruling party legislator in contrast briefly expressed concerns, in a legislative meeting of the Trade, Industry and Energy Committee in April 2013, that Korean firms might be damaged by the requests from their Chinese trade partners to use the renminbi for settlement (NARK, 2013).

Meanwhile, the position of the BoK regarding renminbi use is similar to that of the MoFS. The BoK does not have any policy goal of reducing its use of the dollar despite the global crisis, as the contemporary international monetary system is still a dollar-centred one. ${ }^{44}$ The BoK aims to maintain a share of dollar assets in its foreign exchange reserves comparable to the world average level. ${ }^{45}$ The BoK is interested in diversifying its reserve assets, but 'qualitatively rather than quantitatively (Lee, 2012b)', and also in terms of 'asset types rather than currency composition'. ${ }^{46}$ In fact, while the share of the dollar in the BoK's foreign exchange reserves has declined a bit in recent years, this has been due largely to the currency's depreciation rather than to any BoK policy aimed at reserve currency diversification. ${ }^{47}$ One BoK official commented that 'Investment in the renminbi will be conducted only gradually from the long term perspective, so that there will be no large change in the currency composition of the bank's foreign exchange reserves (Yang, 2012)'. Another official has said in addition that 'The BoK's investment in the renminbi in the future will be determined based on the situation of renminbi internationalisation', ${ }^{48}$ implying that the central bank will merely follow the markets rather than attempting to lead them, in an approach similar to that of the MoFS.

In fact, although as mentioned above the BoK has signed an agreement with the PBoC on using their local currency swap arrangement for trade settlement between the two

\footnotetext{
${ }^{41}$ Author interview with an anonymous MoFS official, 13 September 2013, by telephone.

${ }^{42}$ Author interview with an anonymous MoFS official.

${ }^{43}$ Author interview with an anonymous BoK official (A), 9 September 2013, Seoul.

${ }^{44}$ Author interviews with an anonymous BoK official (B), 9 September 2013, Seoul; and with an anonymous BoK official (C), 13 September 2013, by telephone.

${ }^{45}$ Author interview with an anonymous BoK official (C).

${ }^{46}$ Author interview with an anonymous BoK official (C).

${ }^{47}$ Author interview with an anonymous BoK official (C).

${ }^{48}$ Author interview with an anonymous BoK official (B).
} 
countries, the BoK - and the MoFS, which was also involved in the arrangement - stressed at the time that their main objective was not to encourage use of the renminbi in Korea but instead to help internationalisation of the Korean won (BoK and MoFS, 2012; MoFS, 2013), ${ }^{49}$ although its aim in this regard is fairly modest, focused primarily on increasing the won's role in trade settlement. ${ }^{50}$ Chinese firms are of course unlikely to have strong interest in using the won for trade settlement. Indeed, the Korean authorities judge that the won is only being used for trade settlement between Korean parent firms and their Chinese subsidiaries, given that more than half of Korea's trade with China is of this type (Oh, 2012). ${ }^{51}$ The Korean authorities plan to expand their bilateral local currency swaps with the country's other large trade partners as well to promote won internationalisation. And in October 2013, for example, the BoK did indeed sign local currency swap arrangements with the United Arab Emirates and Malaysia, following which it signed two more in early2014 - with Australia in February and with Indonesia in March.

One of the most direct factors explaining the indifferent position of the Korean authorities toward renminbi use appears to be the lack of interest in the renminbi of the Park Geun-hye administration, which took power in February 2013. The administration has announced a total of 140 major 'administrative tasks' that it plans to achieve during its office, but the list does not include anything related to the renminbi or to currency diversification, although the administration does appear to have a more friendly attitude toward China than that of the preceding Lee Myung-bak administration.

It still needs to be explained why the renminbi is then not an important issue for the Korean government. One answer, first of all, might be the large number of politically important domestic issues that need addressing immediately, while the significant development of renminbi internationalisation seems a matter of the distant future. Second, Korea's political economic position between the United States and China may be affecting the government's attitude toward the renminbi. While its economic ties with China have been deepening, Korea has a critical security relationship with the United States, and its economic ties with that country also remain strong. With the conflicts it faces in this regard thus growing, Korea has generally behaved as an 'active hedger' in response to the rise of China, seeking an optimal balance in its relationships with the two powers so as not to antagonize either one (Chung 2009/2010, pp. 665-66). In such a situation, following the markets with regard to the renminbi may be a reasonable policy choice for the Korean authorities. ${ }^{52}$ Moreover, some Korean public officials appear worried that the growing use of the renminbi might deepen Korea's dependence on China, and this may also have

\footnotetext{
${ }^{49}$ Prior to the arrangement the MoFS revised the foreign exchange regulations in order to facilitate use of the won in China (MoFS, 2013).

${ }^{50}$ Author interview with an anonymous MoFS official.

${ }^{51}$ Sceptics of the feasibility of won internationalisation argue that, given that Korean firms' Chinese subsidiaries mostly use the renminbi or the dollar, it might be difficult to expect them to use the won (Oh, 2012).

${ }^{52}$ Meanwhile, Stokes (forthcoming, pp. 18-19) argues that the security reliance on the United States of many Asian countries, including Korea and Japan, leads them to support the current dollar-centred monetary system.
} 
negative impacts on it. ${ }^{53}$ For example, if the Korean economy's dependence on China were to increase due to renminbi internationalisation, it might need to consider not only US monetary policy but also Chinese monetary policy, which would likely constrain Korea's own domestic monetary policy significantly (Hyun and Chang, 2013).

Finally, it should be noted as well that the Korean authorities' indifference to the renminbi reflects to some extent the lack of interest of the private sector in the currency's use. In fact, private sector demands for increasing renminbi use are strong in the countries whose governments have provided strong policy support to encourage its use, such as the United Kingdom, Singapore and Taiwan as mentioned above (Hornby and Jenkins, 2013; Muk, 2013b; Song, 2013b). In the cases of the United Kingdom and Singapore, the strong private sector demand may be because the two countries are traditional international financial centres with competitive global financial institutions, which appear to have keen interest in preoccupying the potentially lucrative renminbi markets. Taiwan meanwhile has a peculiar political relationship with China, in addition to their close economic ties. In contrast Korea, which as analysed above is an 'ordinary' country, has no strong domestic actors supporting increased use of the renminbi.

\section{CONCLUSION}

As renminbi internationalisation has made an impressive start, the research on it has accordingly grown rapidly. However, while the supply side of the issue of renminbi internationalisation has been addressed to a considerable extent, the demand side has remained significantly underexplored. This paper has attempted to fill this important gap in the literature by providing an in-depth study of the use of the renminbi in Korea, an 'ordinary' foreign country.

It has found that, in contrast to the rapid development of the offshore renminbi market seen in Hong Kong, use of the renminbi in Korea is still marginal. It has furthermore demonstrated that both the private and the public sectors in the country have little voluntary desire to increase their use of the renminbi in the near future. They are interested in using the renminbi after it has established itself as a consequential international currency, but do not wish to become first movers in this regard as that would be costly for them. Korean firms can do little with the renminbi they have acquired, as the opportunities for investment in renminbi-denominated assets are significantly limited, and renminbi transaction costs are high. Korean banks have not developed competitiveness in the renminbi business, either.

In the absence of voluntary private sector incentives for use of the renminbi, the outcome might still have differed had there been policy support from the Korean government to help or to encourage it. Indeed, some countries in peculiar situations have seen this happen, for example those with traditional international financial centres like London and Singapore, whose domestic political dynamics appear to favour growing use of the renminbi, and those having special political relations with China like Taiwan. In contrast to such countries' cases, the authorities in Korea, an 'ordinary' foreign country, have little intention of supporting any expansion in renminbi use in the country, being

\footnotetext{
${ }^{53}$ Author interview with Lee Bong-Geol.
} 
rather more interested in promoting the internationalisation of their own currency, the won. There are also a great many issues of much greater immediate domestic political importance than the renminbi that the Korean government must deal with. In addition, the country's position between the United States and China may have been holding the Korean authorities back from responding more actively to the renminbi in either a 'balancing' or an 'accommodating' way.

These findings raise an important note of caution concerning assessment of the progress of renminbi internationalisation. A growing number of authors appear to be quite confident that internationalisation of the renminbi is 'inevitable', given China's economic rise. And indeed, as mentioned earlier, some studies even argue that a renminbi bloc has already been established in East Asia, suggesting the emergence of a multipolar global currency system. This paper has however demonstrated that, even in Korea, which has very deep and growing economic ties with China, use of the renminbi is still quite limited. More importantly, it has also shown that Korea has little interest in increasing its use of the renminbi as either a medium of exchange, a unit of account or a store of value - at least in the near future up until a time when the renminbi somehow becomes widely used in the world. These findings suggest that renminbi internationalisation may not be inevitable, implying instead the strong inertia in use of the dollar.

In fact, although the global use of the renminbi has grown rapidly, its scope is still substantially limited as its expansion in use has come from a very low base. According to the Society for Worldwide Interbank Financial Telecommunication (SWIFT), a payments company, the share of the renminbi in total global payments still accounted for only 1.12 per cent in December 2013, although it had made a remarkable jump in rank from 20th in the world in January 2012 to eighth. Likewise, the renminbi accounted for a mere 2.2 per cent (out of a total 200 per cent) of global foreign exchange market turnover in 2013, although this was a great rise from its 0.5 per cent in 2007 (BIS, 2013). ${ }^{54}$ According to the Currency Composition of Official Foreign Exchange Reserves database of the International Monetary Fund, the renminbi still belongs to the 'other currencies' category, which accounted for a mere 2.9 per cent of total allocated reserves worldwide in the third quarter of 2013. Moreover, the recent growing use of the renminbi is to some extent due to unreliable factors, such as expectations of renminbi appreciation and arbitrage by Chinese firms. ${ }^{55}$ If these factors disappear someday, the growth of renminbi use may slow. Further, among non-residents outside of China the renminbi is rarely used for transactions among themselves not involving participation from China, although such use is one characteristic required for a currency's being regarded a key international one like the dollar (Kroeber, 2013, pp. 4-5).

The findings of this study may be applicable to countries having economic and political situations similar to those in Korea, with one such country perhaps being Japan. And this

\footnotetext{
${ }^{54}$ The sum of the percentage shares of individual currencies totals 200 rather than 100 per cent, since there are two currencies involved in each transaction.

${ }^{55}$ There is a strong suspicion that Chinese firms use renminbi-denominated L/Cs as means of arbitraging differences between mainland and offshore interest rates. See Cookson (2012), Kynge (2014), Noble (2013) and Thornton (2012, p. 10).
} 
implies that renminbi internationalisation may be limited even in the North East Asian region, although Taiwan appears to have aims of growing as an offshore renminbi market. That said, this research is fully aware of the limitations on generalizability of its findings. There may be other ordinary foreign countries where use of the renminbi is more preferred than in Korea. Indeed, some South East Asian countries-Malaysia and Thailand, for example - appear to be interested in increasing their uses of the renminbi. ${ }^{56}$ And in fact, a comparative study of these two contrasting groups of countries can be expected to contribute significantly to the study of renminbi internationalisation and, ultimately, of currency internationalisation in general, as it is likely to provide an account of the conditions under which countries are more and less willing to use a particular foreign currency for their international transactions. Such a comparative study is beyond the scope of this research, although it should be emphasised that this study does contribute significantly to the literature even in that regard, by calling attention to the need for such demand-side research on currency internationalisation through its own in-depth analysis of renminbi use in Korea, one of China's closest neighbours and economic partners.

\section{ACKNOWLEDGEMENTS}

I wish to thank the Economic Research Institute of the Bank of Korea for offering me a visiting scholar position for this study during August and September 2013. I am also grateful to seminar participants at the Bank and to Michael Marking for helpful comments.

\section{REFERENCES}

BIS (Bank for International Settlements) (2013), 'Triennial Central Bank Survey: Foreign Exchange Turnover in April 2013: Preliminary Global Results' (Basel), available at http://www.bis.org/publ/rpfx13fx.pdf.

BoK (Bank of Korea) (2013a), 'Foreign Currency Deposits By Residents at End-October' (in Korean), press release, 7 November (Seoul).

BoK (2013b), 'The Dim Sum Bond Market in Hong Kong' (in Korean), 14 January (Seoul).

BoK (2013c), 'The Agreements regarding the Bilateral Currency Swap at the Korea-China Summit' (in Korean), press release, 27 June (Seoul).

BoK (2013d), 'The Launching of CNH HIBOR by the Hong Kong Treasury Market

Association' (in Korean), report by Hong Kong office, 24 June (Seoul).

BoK and MoFS (Ministry of Finance and Strategy) (2012), 'The Introduction of a System for Use of the Korea-China Currency Swap for Trade Settlement' (in Korean), press release, 4 December (Seoul).

Campanella, M. (2014), 'The Internationalization of the Renminbi and the Rise of a Multiploar Currency System', ECIPE Working Paper (Belgium: European Centre for International Political Economy).

\footnotetext{
${ }^{56}$ For instance, the QFII quota of the Malaysian central bank is far higher than that of the BoK, reaching 1 billion dollars (Muk, 2013a).
} 
Chen, X. and Y.-W. Cheung (2011), 'Renminbi Going Global', China \& World Economy, 19, 2, 1-18.

Chey, H.-K. (2012), 'Theories of International Currencies and the Future of the World Monetary Order', International Studies Review, 14, 1, 51-77.

Chey, H.-K. (2013), 'Can the Renminbi Rise as a Global Currency? The Political Economy of Currency Internationalization', Asian Survey, 53, 2, 348-68.

Chey, H.-K. (2014), 'Political Economy of Currency Internationalisation', in T. Oatley and W. K. Winecoff (eds.), Handbook of the International Political Economy of Monetary Relations (London: Edward Elgar Publishing).

Chinn, M. and J. A. Frankel (2008), 'Why the Euro Will Rival the Dollar', International Finance, 11, 1, 49-73.

Choi, Y.-M. (2011), 'A Study of the Costs and Benefits of Renminbi Trade Settlement' (in Korean), Trade Focus 11-5 (Seoul: Institute for International Trade).

Chung, J. H. (2009/2010) 'East Asia Responds to the Rise of China: Patterns and Variations', Pacific Affairs, 82, 4, 657-75.

Chung, S. (2013), 'Decrease in QFII Quota of Korea Development Bank by \$10m' (in Korean), Yonhap Infomax, 17 July (Seoul).

Cohen, B. J. (2012), 'The Yuan Tomorrow? Evaluating China's Internationalisation Strategy', New Political Economy, 17, 3, 361-71.

Cohen, B. J. (2014), 'Will History Repeat Itself? Lessons for the RMB', ADBI Working Paper Series No. 453 (Tokyo: Asian Development Bank Institute).

Cookson, R. (2012), 'Renminbi's Mysterious Rise: Trade Finance or Interest Arbitrage?', Financial Times, 29 May (London).

Craig, R. S., C. Hua, P. Ng and R. Yuen (2013), 'Development of the Renminbi Market in Hong Kong SAR: Assessing Onshore-Offshore Market Integration', IMF Working Paper WP/13/268 (Washington, D.C.: International Monetary Fund).

Dobson, W. and P. R. Masson (2009), 'Will the Renminbi Become a World Currency?', China Economic Review, 20, 1, 124-35.

Eichengreen, B. (2013), 'Number One Country, Number One Currency', The World Economy, 36, 4, 363-74.

Eichengreen, B. and M. Kawai (2014), 'Issues for Renminbi Internationalization: An Overview’, ADBI Working Paper No. 454 (Tokyo: Asian Development Bank Institute).

Euromoney (2013), 'China RMB Debate: The Renminbi’s Road to Full Internationalization', July (London).

Frankel, J. and S.-J. Wei (1994), 'Yen Bloc or Dollar Bloc', in T. Ito and A. O. Krueger (eds.) Macroeconomic Linkages: Savings, Exchange Rates and Capital Flows (Chicago: University of Chicago Press), 295-355.

Fratzscher, M. and A. Mehl (2011), 'China's Dominance Hypothesis and the Emergence of A Tri-polar Global Currency System’, ECB Working Paper No. 1392 (Frankfurt: European Central Bank).

Helleiner, E. and A. Malkin (2012), 'Sectoral Interests and Global Money: Renminbi, Dollars and the Domestic Foundations of International Currency Policy', Open Economies Review, 23, 1, 33-55. 
Hornby, L. and P. Jenkins (2013), 'Chancellor George Osborne Cements London as Renminbi Hub', Financial Times, 15 October (London).

Hwang, Y.-S. (2011), 'Renminbi Trade Settlement and Korean Firms' (in Korean), KOCHI Report 11-01 (Seoul: Korea Trade-Investment Promotion Agency).

Hyun, S. and H. Chang (2013), 'Asian Financial Markets: Internationalization of the Renminbi' (in Korean), BOK Working Paper 2013-5 (Seoul: the Bank of Korea).

Ito, T. (2010), 'China as Number One: How about the Renminbi?', Asian Economic Policy Review, 5, 2, 249-76.

Jones, C. (2013), 'Four Key Questions on the Internationalisation of the Renminbi', Financial Times, 15 October (London).

Kawai, M. and V. Pontines (2014), 'Is There Really a Renminbi Bloc in Asia?', ADBI Working Paper Series No. 467 (Tokyo: Asian Development Bank Institute).

Kim, E. (2013), 'Internationalisation of the Reminbi and Its Use in Korea' (in Korean), China Financial Market Focus, Summer, 49-64.

Kroeber, A. (2013), 'China's Global Currency: Lever for Financial Reform', Monograph Series Number 3 (Beijing: Brookings-Tsinghua Center for Public Policy).

Kwon, Edward (2013), 'The Power of Money: Internationalization of Chinese Yuan', paper presented at the 2013 International Studies Association Annual Convention, 3 to 6 April, San Francisco, CA.

Kynge, J. (2014), 'Renminbi's Payments Use Jumps in December', Financial Times, 23 January (London).

Lee, Jong-Wha (forthcoming), 'Will the Renminbi Emerge as an International Reserve Currency?', The World Economy.

Lee, S. (2012a), '41\% of Chinese Firms Say "We Will Offer 3\% Discount for Renminbi Trade Settlement"' (in Korean), Asian Economy (Seoul), 31 October.

Lee, Y. (2012b), 'BoK Starts Diversification of Foreign Exchange Reserves', (in Korean), Hankook Ilbo, 6 March (Seoul).

Liao, S. and D. E. McDowell (2013), 'Redback Rising: Bilateral Swap Agreements and China's Strategy for RMB Internationalization', paper presented at the 2013 International Studies Association Annual Convention, 3 to 6 April, San Francisco, CA.

Mallaby, S. and O. Wethington (2012), 'The Future of the Yuan: China's Struggle to Internationalize Its Currency', Foreign Affairs, 91, 1, 135-46.

MoSF (Ministry of Strategy and Finance) (2013), 'First Renminbi Loans through the Korea-China Currency Swap Provided to Support Trade Settleemnt' (in Korean), press release, 28 January (Seoul).

Moon, H. (2011), '78\% of Respondents Say "We Have Plans to Settle Trade in Renminbi", (in Korean), MK Weekly, 29 June (Seoul).

Muk, E. (2013a), 'Malaysia's Central Bank Gets Third Highest QFII Quota', AsianInvestor, August 1 (Hong Kong).

Muk, E. (2013b), 'Singapore to Get Rmb50 Billion of RQFII Quota', AsianInvestor, 23 October (Hong Kong). 
NARK (National Assembly of the Republic of Korea) (2011), '2011 Assembly Records of the Inspection of the Ministry of Strategy and Finance' (in Korean), Strategy and Finance Committee, 9 September, Seoul.

NARK (2013), 'Minutes of the Trade, Industry and Energy Committee Meeting' (in Korean), 23 April, Seoul.

Noble, J. (2013), 'Renminbi Trade Finance: Less than Meets the Eye', Financial Times, 3 December (London).

Oh, J. (2012), 'Internationalization of the Won Takes Off... Bright Future?' (in Korean), Yonhap Infomax, 5 December (Seoul).

Park, Y. C. (2010), 'RMB Internationalization and Its Implications for Financial and Monetary Cooperation in East Asia', China \& World Economy, 18, 2, 1-21.

Parker, G., S. Fleming and P. Jenkins (2013), 'UK Opens Doors to Chinese Banks with Special Terms for Lenders', Financial Times, 14 October (London).

Pettis, M. (2012), 'The Pace of Financial Sector Reform', available at http://www.stratfor.com/the-hub/pace-financial-sector-reform.

Song, J. (2013a), 'Taiwan Bolsters Its Renminbi Market', FinanceAsia, 13 September (Hong Kong).

Song, J. (2013b), 'Taiwan Nears Formosa Bonds Landmark', FinanceAsia, 4 December (Hong Kong).

Standard Chartered (2013), 'Renminbi Globalisation Index Rose 3.7\% in April', available at http://www.standardchartered.com/en/news-and-media/news/global/2013-06-10global-renminbi-index-up-April.html.

Stokes, D. (forthcoming), 'Achilles' Deal: Dollar Decline and US Grand Strategy after the Crisis', Review of International Political Economy.

Subacchi, P. (2013), 'Expanding Beyond Borders: The Yen and the Yuan', ADBI Working Paper Series No. 450 (Tokyo: Asian Development Bank Institute).

Subramanian, A. (2011a), Eclipse: Living in the Shadow of China's Economic Dominance (Washington, D.C.: Peterson Institute for International Economics).

Subramanian, A. (2011b), 'Renminbi Rules: The Conditional Imminence of the Reserve Currency Transition', Working Paper WP 11-14 (Washington, D.C.: Peterson Institute for International Economics).

Subramanian, A. and M. Kessler (2012), 'The Renminbi Bloc Is Here: Asia Down, Rest of the World to Go?', Working Paper WP 12-19 (Washington, D.C.: Peterson Institute for International Economics).

SWIFT (2014), 'RMB Breaks into the Top Ten Most-used Currencies for Payments', available at http://www.swift.com/assets/swift_com/documents/products_services/RMB_tracker _January2014_final_sdc.pdf.

Thornton, A. (2012), 'Anaemic Ascent: Why China's Currency Is Far from Going Global', analysis (Sydney: Lowy Institute for International Policy).

Wu, F. (2009), 'The Renminbi Challenge', The International Economy, Fall, 32-35, 53.

Wu, F., R. Pan and D. Wang (2010), 'Renminbi's Potential to Become a Global Currency', China \& World Economy, 18, 1, 63-81. 
Yang, I. (2012), 'BoK to Participate in Chinese Stock and Bond Markets' (in Korean), Chosun Ilbo, 18 January (Seoul).

Yu, Y. (2014), 'How Far Can Renminbi Internationalization Go?', ADBI Working Paper Series No. 461 (Tokyo: Asian Development Bank Institute). 